\title{
USING OF SPENT CEREALS STRAW WITH OLIVE CAKE AND SPENT CEREALS STRAW WITH TOMATO POMACE ON FATTENING AWASSI LAMBS
}

Al Barakeh, F. ${ }^{*}$; F.A. Elyassin ${ }^{\star *}$ and M. Al Myzeid ${ }^{\star *}$

* Jordan I National Center for Agric. Res. and Technology transfer

${ }^{\star \star}$ Agriculture faculty, Aleppo University

\section{ABSTRACT}

This experiment was conducted to use spent cereals straw mixed with olive cake(SCO)and spent cereals straw mixed with tomato (SCT) from Pleurotus ostreatus mushroom as animal feed. In completely randomized design, twenty one male lambs, with initial weight $27 \pm 1.0 \mathrm{~kg}$ were allocated to three groups(1.untreated cereals straw (UCS), 2.Spent cereals straw with tomato pomace ( SCT) and 3. Spent cereals straw with olive cake (SCO) ).

The final live weight of the lambs received diets 1,2 and 3,44.4, 44.2 and 43. 3 $\mathrm{kg}$ respectively and their corresponding average daily gain were 191.0,189.0 and $178.0 \mathrm{~g} /$ day / animal. The average feed intake were $108.8,107.0$ and $97.0 \mathrm{~kg}$ in 90 days, respectively, which were significantly $(p<0.001)$ lower for SCO. Feed conversion ratio was $6.33,6.32$ and 6.51 respectively, which were not statistically different among the groups. This experiment showed that the spent compost of the cereals straw with olive cake and cereals straw with tomato pomace can be used only as a roughage in the lambs fattening diets.

Keywords: Spent cereals straw with olive cake, spent cereals straw with tomato pomace and lambs fattening.

\section{INTRODUCTION}

In Jordan there is around 200,000 tons of straw and there is much interest in the possible use of cereal straws in ruminant livestock feeding ,also Jordan produce 25000 tons of olive cake and 500 tons of tomato pomace ,all these by products are characterized that contain high lignin, cellulose hemi cellulose and low digestibility, so its utilization by the animals is limited because of the low voluntary intake and their huge bulk which makes transportation more costly(Balch,1976).The crop residue contain 30-40\% cellulose, $16-27 \%$ hemi cellulose and 3-13\% lignin(Chahal,1991).In order to increase the digestibility of the these by products the attention was increase to use the white-rot fungi because its capacity to remove the lignin preferentially(Pilon et al.,1982).According to Durrant et al.(1991) fungal cultivation resulted in considerable changes in the spent straw, remained after mushroom harvested, leading to the increase of crude protein and cellwall-soluble contents which might be more useful than untreated straw ,fed to ruminants. Meanwhile, inclusion of spent wheat straw obtained from cultivation of Agaricus bisporous mushroom in the diet of buffalo, up to $25 \%$,resulted in a similar nutrient digestibility but a lower dry matter intake, comparing to the control diet(Langer et al.,1982).Adamovic et al.(1998)inculcated the Pleurotus ostreatus on wheat straw and they used the spent compost as a part of the cattle diet in a feeding trail lasted 57 days

\footnotetext{
*Corresponding author, Faisal Al Barakeh,faisal_barakeh@yahoo.com
} 
,they found that steers would not consumed mixed ration with more than $17 \%$ dry matter of the spent compost. The decrease in daily gain and feed conversion was observed with increase of amount of spent compost .Fazaeli and Shafeyi ( 2005 ) reported that the spent compost straw could not be include up to $15 \%$ of the finishing lambs diet. Other researchers (El-tahan et al .,2003)found that the spent straw could replace concentrate feed mixture up to $40 \%$ for feeding growing lambs.

The aim of this work was to study the effect of spent cereal straw with olive cake and the spent of cereal straw with tomato pomace as a roughage on the growth performance of fattening lambs.

\section{MATERIALS AND METHODS}

Compost of pleurotus ostreatus spent cereal straw with olive(SCO) cake and cereals straw with tomato pomace( SCT)were obtained from a mushroom production unit (AI Khanasry station) in Jordan. The first compost had been made by mixing cereal straw $(600 \mathrm{~kg})$, olive cake $(300 \mathrm{~kg})$, wheat bran $(50 \mathrm{~kg})$ and gypsum $(50 \mathrm{~kg})$. The second compost had been made by mixing cereal straw $(600 \mathrm{~kg})$,tomato pomace $(300 \mathrm{~kg})$, wheat bran $(50 \mathrm{~kg})$ and gypsum $(50 \mathrm{~kg})$. After the mushroom harvesting (5 times)which was completed within 8to 10 weeks post spawning ,the bags of composed cereals straw with olive cake and cereals straw with tomato pomace were removed from the growing room, left in cement yard for sun drying, samples for chemical analysis was taken.

Twenty one Awassi lambs with initial weight of $27 \pm 1.0 \mathrm{~kg}$ were housed in individual boxes and allocated to the experiment for 90 days. Three experiment diets were formulated

1.Control group, fed concentrate, and adlibetum untreated cereals straw (UCS).

2. Treatment group 1, fed concentrate and adlibetum spent cereals straw with olive cake (SCO).

3. Treatment group 2, fed concentrate and adlibetum spent cereals straw with tomato pomace (SCT).

All the lambs received their requirement from the concentrate (Table 2 ) according to NRC (1986), and adlibetum untreated cereals straw or spent cereals straw with olive cake and cereals straw with tomato pomace (Table 1). Cereals straw, spent cereals straw with olive cake, cereals straw with tomato pomace and concentrate were fed separated two times a day.

During the experiment, daily voluntary feed intake, body weight and daily gain of each lamb were individually recorded, feed conversion ratio were estimated. Data were statistically analyzed, according to the completed randomized design, using SAS GLM procedure (1996).

\section{RESULTS AND DISCUSSION}

\section{Chemical composition:}

Results of chemical composition showed (Table 1) that the spent by products remained from Plerurotus ostreatus cultivated contained a considerable amount of crude protein (CP). The restively higher amount of 
CP in spent by products (from 4.46 to $9.59 \%$ in SCO and from 7.26 to 13.63 $\%$ in SCT)could be because this type of by products rich of microorganism .extra cellular enzymes and contained relatively a high level of nitrogen(Ball and Jackson ,1995).

Table(1) The chemicals analysis and fiber fraction of treated and untreated olive cake with cereals straw and tomato pomace with cereals straw(as DM basis)

\begin{tabular}{|l|c|c|c|c|c|}
\hline & UCS & SCO & UCO & SCT & UCT \\
\hline Dry Matter & 92.2 & 92.8 & 92 & 91.7 & 90.1 \\
\hline Organic Matter & 76.90 & 81.57 & 88.42 & 77.21 & 81.90 \\
\hline Crude Protein & 3.69 & 9.59 & 4.46 & 13.63 & 7.26 \\
\hline Crude Fiber & 25.73 & 25.22 & 33.22 & 19.84 & 28.77 \\
\hline Ether Extract & 0.37 & 0.40 & 1.79 & 1.82 & 3.35 \\
\hline Nitrogen free Extract & 47.11 & 46.36 & 48.95 & 41.92 & 42,52 \\
\hline Ash & 23.10 & 18.43 & 11.58 & 22.79 & 18.1 \\
\hline NDF & 77.55 & 64.45 & 85.34 & 54.0 & 76.03 \\
\hline ADF & 52.18 & 43.31 & 60.25 & 38.31 & 57.15 \\
\hline ADL & 15.97 & 14.61 & 24.82 & 23.16 & 16.58 \\
\hline Cellulose & 36.21 & 28.70 & 35.97 & 15.15 & 40.57 \\
\hline Hemi cellulose & 25.37 & 21.14 & 25.09 & 15.69 & 18.88 \\
\hline Lignin & 12.74 & 12.04 & 23.22 & 17.52 & 12.71 \\
\hline
\end{tabular}

SCO=Spent cereals straw with olive cake.

UCO=Untreated cereals straw with olive cake.

SCT=Spent cereals straw with tomato pomace.

UCT $=$ Untreated cereals straw with tomato pomace.

UCS= Untreated cereals straw.

The concentration of crude fiber (CF),neutral detergent fiber (NDF) and acid detergent fiber (ADF) were lower in the SCO and SCT comparing to the untreated ,however this by products contained a low level of organic matter $(\mathrm{OM})$ and its utilization is limited because of high level of ash . The lower amount of NDF and ADF could be as a result of OM decreasing in the SCO and SCT, which similar to the result reported by others(Fazaeli and Shafey,2005;El-tahan et al .,2003 ; Mahrous and Abo Ammuo,2005) .

The high level of ash is due to the depletion and consumption of $\mathrm{OM}$ of straw by the fungi.The ash content of SCO and SCT increase form 11.58$18.43 \%$ and from 18.1 to $22.79 \%$ respectively,this result agreed with Adamovic et al.(1998), Fazaeli and Shafey(,2005)and El-tahan et al .,(2003).

The animal performance:

The animal performance results showed(Table 2) that the final weight of the lambs received untreated cereals straw (UCS),SCT and SCO were $44.4,44.2$ and $43.3 \mathrm{~kg}$,the average daily gains were $191.0,188.8$ and $177.9 \mathrm{~g}$ per animal respectively, which were significantly $(p<0.001)$ higher for the animals received UCS and SCT. It could be as result of the lower SCO intake by the animals. The average quantity of USC,SCT and SCO received by the animals were $25.18,23.2$ and $16.1 \mathrm{~kg}$ during 90 days, respectively, which were significantly $(\mathrm{p}<0.001)$ higher for UCS and SCT. According to Kakkar et al.,(1990), which utilized mushroom harvested spent straw as feed for 
buffaloes, the voluntary intake decreased due to the relatively high content of ash in the diet.

Table (2).Formulation of the experiment diets fed to Awassi lambs.

\begin{tabular}{|l|c|}
\hline Ingredients & percents \\
\hline Barley grain & 50.0 \\
\hline Corn grain & 30.0 \\
\hline Soybean meal & 11.0 \\
\hline Wheat bran & 7.0 \\
\hline Salt & 1.0 \\
\hline Limestone & 1.0 \\
\hline \multicolumn{2}{|c|}{} \\
\hline Crude protein \% & 13.20 \\
\hline ME(Mcal/ kg) Chemical analysis \\
\hline TDN \% & 2.66 \\
\hline
\end{tabular}

${ }^{*}$ Mc Donald,73

Also fazaeli and shafey (2005) reported that the utilization of the spent straw by the animals is limited because of the low organic matter and high mineral content ,which may reduce its acceptability and nutrient balance and they reported that the spent compost straw could be include up to $15 \%$ per $100 \mathrm{~kg}$ of the diet for finishing lambs. The results in (Table 2) shows the amount of UCS ,SCT, and SCO rejected by the animals,6.82,8.8, and $15.9 \mathrm{~kg}$, which were significantly $(p<0.01)$ higher for USC. This means that the animals not prefer spent pleurotus compost ,this result agreed with Adamovic et al.(1998); Kakkar et al.,(1990).

Table(3)Feed intake and refusal, initial and final live weights, total feed efficiency and gain and average daily gain

\begin{tabular}{|c|c|c|c|c|}
\hline \multirow[t]{2}{*}{ Variable } & \\
\hline & UCS & SCT & SCO & Significance \\
\hline Roughage (Kg) & 32.00 & 32.00 & 32.00 & \\
\hline Refused & $6.82 \pm 1.5^{\mathrm{a}}$ & $8.8 \pm 1.16^{b}$ & $15.9 \pm 82^{c}$ & ${ }_{* \star \star *}$ \\
\hline Consumed & $25.18 \pm 1.08^{\mathrm{a}}$ & $23.2 \pm 1.5^{b}$ & $16.1 \pm .4^{c}$ & *** \\
\hline \multicolumn{5}{|l|}{ Concentrate (Kg) } \\
\hline Consumed & $83.8 \pm 1.58$ & $83.8 \pm 1.58$ & $80.7 \pm 1.58$ & NS \\
\hline Initial weight $(\mathrm{kg})$ & $27.2 \pm 1.0$ & $27.3 \pm 1.0$ & $27.4 \pm 1.0$ & NS \\
\hline Final weight $(\mathrm{kg})$ & $44.4 \pm 0.7$ & $44.2 \pm 0.7$ & $43.3 \pm 0.7$ & NS \\
\hline Kg feed intake/head/day & $1.21 \pm 0.02^{\mathrm{a}}$ & $1.19 \pm 0.02^{\mathrm{a}}$ & $1.08 \pm 0.02^{b}$ & $\star \star \star *$ \\
\hline Total feed efficiency & $6.34 \pm 0.35$ & $6.33 \pm 0.35$ & $6.10 \pm 0.37$ & NS \\
\hline Total gain $(\mathrm{kg})$ & $17.2 \pm 0.7$ & $16.9 \pm 0.7$ & $15.9 \pm 0.8$ & NS \\
\hline Average daily gain $(\mathrm{g} / \mathrm{d})$ & $191 \pm 8$ & $188 \pm 8$ & $177 \pm 9$ & NS \\
\hline
\end{tabular}

$a, b, c$ Means within the same row with different superscripts differ according to the indicated level of significance

NS = non significant; ${ }^{\star \star \star}=\mathrm{P}<0.001$;

\section{CONCOLUTION}

A considerable by products degradation is achieved by the influence of Pleurotus ostreatus enzymes, particularly of cell wall components, cellulose, hemi cellulose and lignin. From the results obtained in this study it is not possible to conclude that the nutritive value of the cereals straw mixed with 
olive cake and mixed with tomato pomace was improved during mushroom production. So it could be used as a roughage only.

\section{ACKNOWLEDGMENTS}

The author wish to thanks the National Center for Agricultural Research and Technology Transfer (NCARTT), and Middle East Regional Agricultural Program.

\section{REFERENCES}

Adamovic,M.,Grubic,G.,Milenkovic,I.Jovanovic,R.Protic,R.Sretenovic and L.Stoicevic.(1998).The obi degradation of wheat straw by Pleurotus ostreatus Anim.Food Sci.Tech.,71:357-362.

Balch,C.C.(1976). The potential of poor quality agriculture roughages for animal feeding.FAO.paper No. 4,Rome.

Ball,A.S.and A.M.Jackson.(1995).The recovery of lignocelluloses-degrading enzymes from spent mushroom compost.Bio-resource Technology. 54: $311-314$

Chahal, D.S. (1991). Lignocelluloses wastes: Biological conversion: Bioconversion of waste materials industrial products. Elavier Applied science London.pp.373-400.

Durrant,A.J.,D.A.Wood and R.B.Cain.(1991).Lignocellulose biodegradation by Agaricus bisporus during solid state substrate fermentation. J. General Microbiol.137:751-755.

El-tahan,A.A.H.,G.A.Abd El-Rahman, M.A.Sarhan and F.F.Abo Ammo (2003). Utilization of mushroom by-products for feeding ruminant.2. Utilization of mushroom by-products for feeding sheep. Egyptian J. Nutrition and feed .6(Special Issue):879-890

Fazaeli,H.and H.Shafeyi.(2005).Using of Mushroom Spent Straw Compost as Animal Feed. Proceeding of the fifth International Conference on Mushroom Biology and Mushroom Product.PP.291-295

Kakkar ,Vk.,H.S. Garch,S. Dhanda and G.S. Makker. (1990). Mushroom harvested spent straw as feed for buffaloes .Indian J. Anim. Nutr. 7(4): 267-272.

Langer,P.N., J.P.Sehgal, V.K.Rana, M.M.Singh and H.S. Garcha. (1982). Utilization of Agaricus bisporus harvested spent wheat straw in the ruminant diets. Indian.J.Anim.Sci.52(8):634-637.

Mahrous A.A and F.F.Abo Ammou.(2005). Effect of biological treatment for rice straw on the productivity performance of sheep. Egyptian $\mathrm{J}$. Nutrition and feed 8(Special Issue):529-540.

N.R.C.(1986). Nutrient Requirement of Domestic animals: Nutrient requirement of sheep.National Research Council, Washington, D.C., U.S.A.

Pilon,s.,M.Barde and M.J.Uraseki. (1982). Fungal treatment .Biotechnol Bioeng. 24:2067-2076.

SAS. (1996).SAS Users Guide: Statistic .SAS Ins.Inc.Editors, Cary,NC. 
تأثير استخدام التبن مع تفل الزيتون والتبن مع تفل البندوره ألمزروع عليها فطر

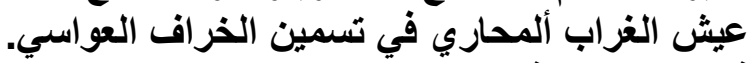

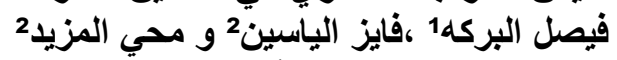

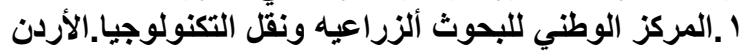

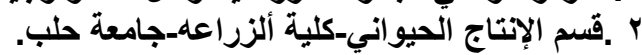

أجريت هذه الدراسة لهعرفة تأثير إستخدام التبن مع تفل الزيتون و التبن مع تفل البندوره

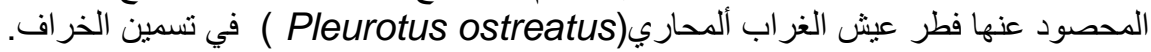

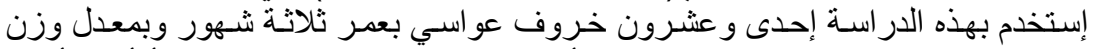

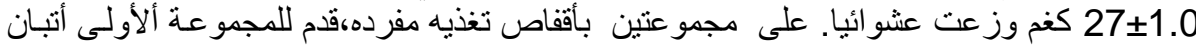

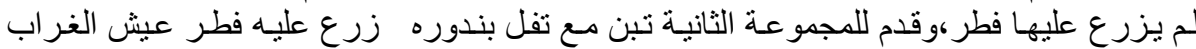

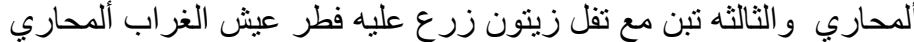

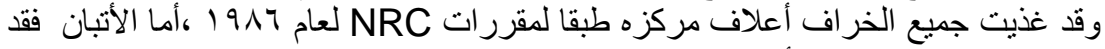

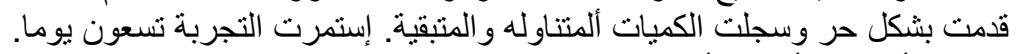

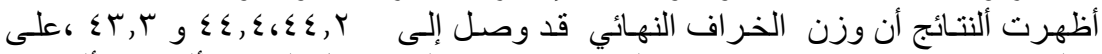

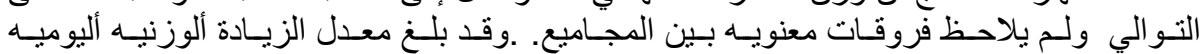

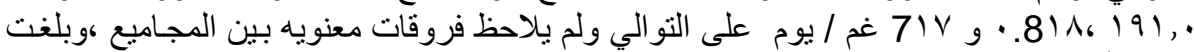

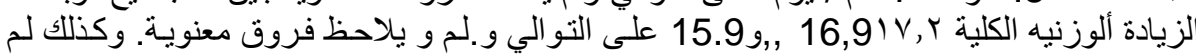
يلاحظ فروق معنوية بين الرجاميع.

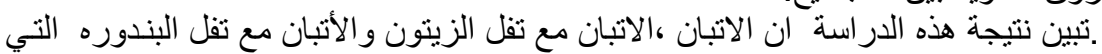

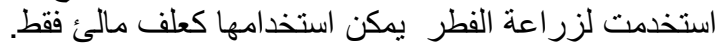

